\title{
Editorial
}

\section{Social and Climate Change: Impact on Human Behavior}

\author{
Koentjoro Soeparno and Budi Andayani \\ Faculty of Psychology \\ Universitas Gadjah Mada
}

\begin{abstract}
The nature of social change occurs at the center of human consciousness and based on a commitment, it cannot be reversed, rejected, or canceled (Vago, 2004). Therefore, there are economic and political orders as a result of conflict of ideologies within society. Historically, global social change is caused by the Industrial Revolution and Ideology and Gender Revolution. The invention of telegraph was the beginning of globalization, identified by the $4 \mathrm{~T}$ revolution (Telecommunications, Transport, Tourism and Transparency). The revolution in agriculture, mining, manufacturing and industry results changes in lifestyle and exploitation of natural resources that can cause climate change. The second source of social change is the revolution of ideology and gender. When colonialism, slavery and deprivation of human rights occurred, the movement to struggle for human rights as its counterculture appeared, resulting in 1980 the pro-human right movement products. The sexual revolution in the 1960s in the USA demanded for equal rights between men and women. The 1975 UNFPA population convention held in Cairo have made an agreement to restrict population growth using contraception, resulting later-on the concept that sex is no longer for reproductive purpose but for recreation. People's lifestyle has changed since then.
\end{abstract}

Keywords: social change, globalization, climate, lifestyle, human rights, gender

Sifat dasar perubahan sosial itu menjadi pusat kesadaran manusia dan terdapat komitmen yang tak dapat dibalik, ditolak, maupun dibatalkan (Vago, 2004). Oleh karena itu di masyarakat juga terdapat tatanan ekonomi dan politik yang diakibatkan oleh konflik ideologi. Dalam konteks kesejarahan perubahan sosial besar di dunia ini disebabkan oleh dua hal pula, yaitu: Revolusi Industri di Inggris pada 1750-1850 dan Revolusi Ideologi dan gender. Penemuan mesin telegraf adalah awal dari globalisasi yang ditengarai oleh revolusi 4T (Telekomunikasi, Transportasi, Turisme dan transparansi). Sumber perubahan sosial kedua adalah revolusi dalam bidang Ideologi dan Gender. Ketika penjajahan, perbudakan dan perampasan hak asasi manusia terjadi, maka munculah perjuangan hak asasi insani sebagai counter culture-nya hingga memunculkan kesadaran hak asasi manusia pada 1980, yang ditengarai dengan munculnya literatur yang bernuansa pro-human right. Revolusi seks pada 1960-an di USA menuntut kesamaan hak antara pria-wanita. Konvensi kependudukan UNFPA 1975 di Kairo menghasilkan pembatasan jumlah penduduk melalui kontrasepsi, sehingga hubungan seks tidak saja untuk kepentingan reproduksi, namun telah berubah untuk kepentingan rekreasi. Kondisi inilah yang kemudian mengubah gaya hidup.

Kata kunci: perubahan sosial, globalisasi, iklim, gaya hidup, hak asasi, gender

As the earth rotates on its axis everyday, the world has constantly changed. Human interaction from time to time will form social change that influences

Part of this article will be presented at the $1^{\text {st }}$ STACLIM 2014 International Conference on Science and Technology Application in Climate Change in Bali, 17-19 November 2014.

Correspondence concerning this article should be addressed to Koentjoro Soeparno, Faculty of Psychology, Universitas Gadjah Mada, Jalan Humaniora No.1 Bulaksumur 55281, Indonesia. E-mail: koentjoro@ugm.ac.id our daily life. The development of science and technology as a result of this change also influences our lifestyle. Social change is commonly regarded as a process, but it is rarely seen as a system. The reason for this, in my opinion, is because within social change, there is a social change and at this point, the efficacy of Darwin's theory is tested and surah al-Asr is completely proven. Basically, life is 
a struggle against time and it is expected that our lives can stand the tests of time.

Vago (2004) explains that social change is natural, it is the center of human consciousness and based on a commitment, it cannot be reversed, rejected, and canceled. There are changes in technology, demographic, ecology, and other changes in economic and political order within a society that were caused by conflict of ideology. Cascio (1998) claimed that social change would transform workplaces and organizations within a company. This is due to changes in social system that influences other systems.

Basically, there are two types of social change: planned and unplanned social change. Construction is a form of planned social change. Wars are planned, but the social change as an impact of wars is unplanned. Earthquakes, natural disasters and social unrest are unplanned changes. Being a single mother, delaying age of marriage and other kind of lifestyle are considered as unplanned social change, but its impact is planned.

\section{Conceptualization of Social and Climate Change and its Impact on Human Behavior}

Different group activities: social change can be defined as modifications of the ways people work, educate, raise families, parent their children, selfmanage, and search for the meaning of life. The changes are formed from various activities conducted by different individuals where each individual participate directly or indirectly in social change, including in climate change.

Changes in the structure of community: the changes include social changes or alteration in the structure of community, such as that in remote and illiterate communities. Changing the structure and function of society: social change does not merely change is the structure of society but also changes its function. Changes in social relationships: this includes changes in human interaction. Changes in social structure and social relationships: social change includes two entities: (1) changes in social constitution as a whole, and (2) changes in relationship with all beings. Definition of social change mechanism: this refers to the comparison between the abstract concept and reality. The changes include changes in social structure, function of society, social relations, forms of social processes, and time. However, it is still difficult to define what changes actually occur.
Social change may result a change in itself. This leads to a change in human behavior in the form of a lifestyle change, exploitation of natural resources, and greenhouse effect that occurs as a result of climate change. As noted by Kurt Lewin that $\mathrm{B}=\mathrm{f} \mathrm{P} \times \mathrm{E}$, behavior or human behavior is the function of personality and environment. Climate change leads to changing in environmental governance, and this will eventually influence human behavior and personality.

Zika Zakiya from the National Geographic Indonesia (2013; as cited in Kompas.com, March 2, 2014) stated that there are six impacts of climate change that will influence the lives of Indonesians:

The rise of food prices in the next few decades. Experts predict that the production of food crops such as corn, wheat, rice, and cotton will decline by 30 percent. A decrease in production may lead to an increase in food prices. This is due to the fact that storage and transportation of food requires water and more energy.

Unusual weather cycle. This indicates that the unusual rise of temperatures along with global population may raise the demand for energy. This will eventually lead to the production of emissions causing a climate change and, ironically, create more production of emissions. It is predicted that rainfall will decline as much as 40 percent in some locations.

Damage to infrastructure. Climate change could lead to more extreme weather that produces a variety of natural disasters and fires as happened in Jakarta on January and February 2013. High intensity of rainfall has caused major flooding on Thursday (17/1). The capital city of Indonesia was paralyzed because almost all roads had been flooded. Roads and buses which are essential for the citizens of Jakarta were no longer functioning. Data from the National Disaster Management Agency (BNPB) showed that 15,423 people had to be evacuated. Submerged area consisted of 720 RT, 309 RW, 73 administrative villages and 31 districts.

Reduced water resources. The explosion and overcrowded population could lead to high demand for water. The usage of water resources might increase dramatically. Particularly in Jakarta, the rise of sea levels may make the boundary between ground water and seawater move into the mainland and this could pollute the sources of drinking water.

Increased number of respiratory disease or infection. Climate change has caused air pollution that eventually influences human health by reducing the function of the lungs. In big cities such as New 
York in the United States, the prevalence of asthma has increased by ten percent.

Hydrological disaster. Natural disasters as a result of climate change may increase the occurrence of hurricane and extreme weather. Only few cities in the world have a mitigation system that can overcome disasters.

\section{Sources of Social And Climate Change And Its Impact On Human Behavior}

Based on the meta-analysis approach, it is concluded that the source of social change in the whole universe is the industrial revolution in England and revolution of ideology and gender.

Vago (2004) argued for several sources of social change:

Technology. Technology (not merely information) plays a crucial role in the rapid pace of social change. This can be seen from positive and negative impacts of technology and the influence of technology on human behavior.

Ideology. Ideology is a complex belief system that includes structure and social and political relations: (a) Ideology and change, Max Weber is an initiator of capitalism who showed the relationships between ideology and change; (b) Ideology in a married family; and (c) Ideology of an ideal society.

Competition. Competition arises due to the gap of possessing luxury goods, status, and other forms of services that are generally desired by everyone. Shari (1999) pointed out that conflict; including both competition and conflict, arises from an effort shown by two or more parties in order to achieve a particular objective. For example, workers vs. manager; university students vs. administrative staff and white vs. black people. Each party has objectives that are sometimes conflicting: (a) Politics; politics is essentially a process to obtain power and decide who gets what, when, and how; (b) Economics; business, industry, and finance play a crucial role in development and social change, supported by the presence of free ownership; (c) Globalization; the world economy has changed dramatically as the result of globalization (Shari, 1999); (d) Structural damage; this refers to a disagreement or conflict between two or more elements within a social system.

\section{Social Change Theories}

Vago (2004) suggests several theories of social change:

\section{Theories of Evolution}

Auguste Comte (1798-1857) is a philosopher who concern about the development of perfect society. Comte argued that perfect society is not the result of a political revolution, but the accuracy of application of moral science that is known as "sociology". In order to achieve a perfect society, three stages are required: theology, metaphysics, and positivistic. Because of this, Comte was named as the Father of Sociology.

Lewis Henry Morgan (1818-1881) is an anthropologist who emphasized that the development of technology and system is dependent on differences in family relationships and political institutions. Based on historical data an the results of studies, it is found that culture around the world has constantly changed.

Herbert Spencer (1820-1903) is known as the second father of sociology. He observed evolution as a development that is not always aligned due to the fact that everything in the cosmos constantly changes and synthesizes at a high level of complexity.

\section{Theories of Conflict}

Conflict theory assumes that social behavior should be understood from the context of tensions and conflicts between groups and individuals.

Karl Marx (1818-1883) is a philosopher, an expert in economics, history and sociology. Karl said that "no conflict, no change". Every society, despite its background emphasized on economic development.

Lewis A. Coser (1913-?) indicated that within social change, conflict has positive and negative impacts. Coser explained that conflict is part of the socialization process and there is no social group that is completely free from conflict. Conflict in society is unavoidable because each individual has a feeling of hate as well as a feeling of love. Thus, conflict is a part of human condition.

Ralf Dahrendorf (1929-unknown) is a sociologist. He argued that social conflict has structural authenticity of which it should be understood as a conflict concerning the legitimacy of authority within a relationship. Inside organization, roles and positions can be divided into two "quasi-groups" where their members oppose the one who is considered as an underdog. The ruling party continues to protect its status quo.

\section{Structural-Functional Theory}

Talcot Parsons (1902-1979) pointed out that social change is a boundary between damage and balanced 
renovation that has two sources: endogenous (influencing the boundary within a system) and exogenous (initiated by other system that is outside the social system). The external pressure (exogenous) of social change is basically an internal factor of another system (personality, organism, culture) which is called as delineate society (public depiction). Exogenous source of social change consists of endogenous tendency to change the functionof the organism, personality, and cultural system.

William F. Ogburn (1886-1959) argued that society operates as a public-housing having astatic mechanism where a change is considered as an obstacle for a balance in which one party tends to produce changes as a compensation for maintaining the balance of the other party. Some experts stated that functional analysis paid more attention to social order rather than social change.

\section{Social Psychology Theories}

Max Weber (1864-1920) emphasized that the spirit of capitalism is one of the characteristics of situation where people are occupied with ideas to 'make money' and an accumulation of possessions has become the main goal of their life. We are always under pressure to think rationally about all our activities.

Everett E. Hagen (1906-1993) stated that changes from traditional to modern society would never be realized without changes in personality. Personality consists of attributes such as creativity, curiosity, and openness to experience.

David C. McClelland (1917-1998) was inspired by Weber's opinion indicating that the orientation of changes in social psychology led to changes in economics and therefore created "industrial capitalism". McClelland is more interested in observing the issue around economic development, particularly an investigation of what is known as an achievment motivation. He stated that both historical and contemporary society is the result of previous economic development (achievement motivation).

\section{Social Change Around Us And Its Impact On Human Behavior}

Up until the early 1990s, only two sources that are used to predict the changes in the world. However, as a result of environmental damage, since 2005 a new phenomenon, a new source of social changes has emerged and this is known as climate change.
Climate change is an issue that is often discussed at present.

Social change can be essentially classified into two causes: social change that comes from the Industrial Revolution in England in the form of technological change that leads to industrialization and capitalism; and social change in the form of changes in ideology and gender. The Industrial Revolution occurred between the years 1750-1850 where massive changes in agriculture, manufacture, mining, transportation, and technology have created a profound impact on social, economic, and culture around the world. The Industrial Revolution started in Great Britain and subsequently spread throughout Western Europe, North America, Japan, and eventually to the rest of the world. These changes are connected with each other, made everything change and influenced human behavior (see Figure 1).

\section{Technological Change}

The results of the industrial revolution in England in the 18th century were changes in engineering and IT. In addition to the changes in industry, people also change following the changes of the system (Cascio, 1998). During the industrial revolution, telegraph was discovered. The discovery of telegraph has started globalization (Kuntjoro-Jakti as cited in Soeparno, 1998). Kuntjoro-Jakti stated that globalization occurred because of 3T revolution. In further development, Soeparno (2003) modified this into 4T, that is: revolution in telecommunication, transportation, tourism and transparency. In fact, the revolution has been slowed down since the industrial revolution in England until the 1960s. However, with the use of satellites, the changes in telecommunication have occurred more rapidly.

The industrialization in England spurred the exploitation of natural resources. The history has recorded that after the industrial revolution in England, the Netherlands fell into crisis, and as a result, natural resources such as rubber and spices in the archipelago were exploited by the VOC and brought to the Netherlands. Industrialization required a supply of basic materials and it was obtained in a large scale. As a result of this, there was massive exploitation of natural resources, particularly in mining and agriculture. Raffles in 1811-1816 came to the archipelago with the same purpose as the VOC.

Industrialization in England created the gap between the rich and the poor. This condition led people to 
live in certain lifestyles. Clearing and burning of polycuture forests in Sumatra, Kalimantan, Sulawesi and Papua, and the efforts to change them into monoculture oil palm forests, has led to environmental degradation and caused climate change.

\section{Revolution in Telecommunication}

The examples of product of telecommunication are radio, television, cell phone, and internet. There have been many changes in telecomunication in the past century. Cellphone which was first released in 1979 has transformed so much and it is no longer just a means of communication. Roughly, the changes in communication especially the media can be divided into: radio, black and white television, color television, flat screen television, and finally, Internet and cellphones.

When radio was popular, community members had close connection and were friendly with one another (guyub or gemeinschaft), the civilization was not yet advanced and therefore, the radio was used as a media for communication, trade, farming, and even romance.

In the era of black-and-white television, the number of TV owners was limited due to its price and availability. The members of society were still close and friendly with one another because the function of television is not much different from radio. The change is only from audio to audio-visual and it is still considered oneway communication.

The age of color television was a period of transition from gemeinschaft to gesselschaft. During this period of time, people went to the district office to watch television. It might seem that people had close connection but in fact, they were all focused on the TV show. It was still an audio-visual and one-way communication media. Flat screen TVs which are larger and comfortable has changed the way people watch TV. Watching TV which was once a communal activity, it is now a personal activity done within a family. The type of communication is still one way using an audio visual media. In theory, families would watch TV together, but this rarely happens because of lack of communication within the family. Ironically, TV shows include bad role models. Broadcasters are busy to increase television show ratings and include advertisement indicating a consumptive-materialistic model. Given that there is no family-role model, children today's show lack of courtesy and good manners as complained by many teachers.

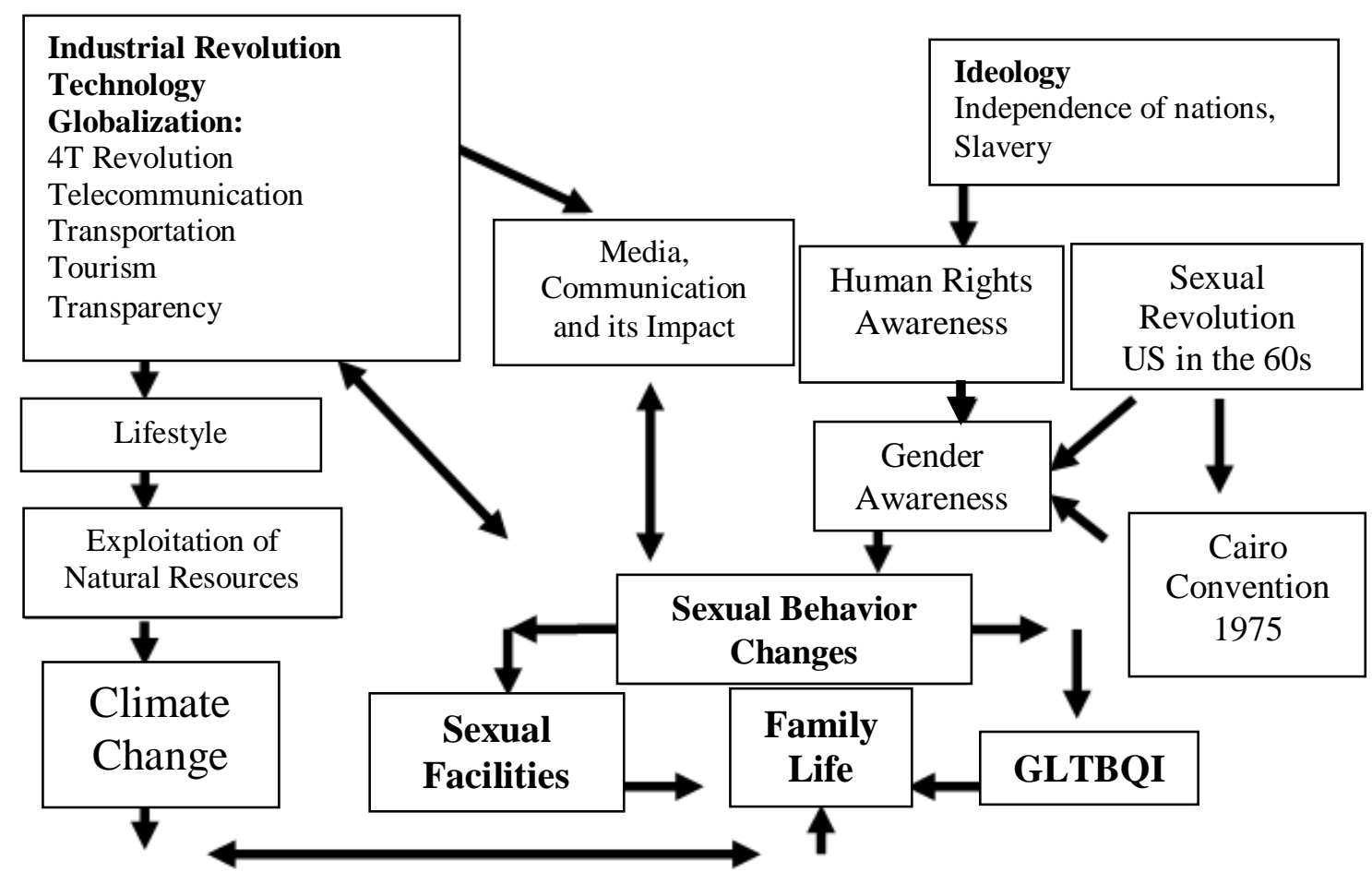

Figure 1. Social change around us and its impact on human behavior. 
Nowadays is the era of Internet and cellphones. There is a two-way communication but people do not interact directly. It is said that people interact with an object and does not recognize emotion. It is therefore children todays are cognitively intellegent but they are lack of empathy. The young generation today is labelled as generation Y. Another change in this era is the construction of radio and television transmitter and telecommunication that need a lot of space. The construction may lead to forest destruction or environmental degradation.

\section{Revolution in Transportation}

Revolution in transportation has created inexpensive and mass transportation. The impact of this revolution is revolution in the field of packaging and packing. As a result smuggling has become rampant.

The number of transportation, particularly motor vehicles has increased from time to time, but the number, size and length of road has not changed. This can create traffic congestion. The impact of traffic congestion and increased number of motor vehicles is pollution. Several studies in psychology indicate that pollutants have an impact on human behavior. The construction of roads and increased number of motor vehicles might cause deforestation and increased pollution from motor vehicle emission. Studies have shown that environmental damage has profound psychological effects on human behavior.

\section{Revolution in Tourism}

Revolution in tourism in Indonesia and even in the world is inhibited by the issue of terrorism and unrest (such as terrorism in Indonesia and pro and cons of prime minister in Thailand). Revolution in tourism has made the number of hotel construction increase sharply, and therefore, it increases the exploitation of ground water. Similarly, destruction of nature and environment has been the result of increased market demands (see the case of Raja Ampat).

\section{Transparency Revolution}

Transparency revolution started to occur with the appearance of paparazzi and infotainment. It is as if a person or an institution could not have secrets. Everything should be opened and publicly accessible. We will be further described this in the section of the latest Indonesian political changes. Transparency is supposed to be used as a medium of control, particularly for media. Since media is often owned by a certain group of people that have certain interests, many issues of environmental degradation that influence climate change has not been exposed.

\section{Changes in Ideology}

Ideological Revolution has been caused by two social phenomena which are: (a) countries gained indipendence in the 20th century; and (b) the end of slavery in the 1970's.

Gaining independence indicate that the colonized and the oppressed have constantly struggled for independence. Thus, the condition of those who were colonized has become the foundation or inspiration for the struggle towards Human Rights.

In the 1960s in America, sexual revolution was initiated by a group of women's liberation who demanded equality of roles and responsibilities between men and women and expressed that sex was for pleasure. This revolution and the condition of the world that enter the era of postmodernism, has inspired gender equality movements. This is the reason when referring to western publication, there are significant different nuances between scientific papers written before and after 1990. The scientific work after 1990 has contained many issues of gender and feminism.

In 1975 in Cairo, UNFPA conducted a convention discussing the balance between world population and the availability of food. Malthus' law seemed to become closer to the reality. This issue had been used as a basis for holding a convention on world population. Discussion included the use of contraceptives to reduce the growth of world population. On one hand the decision made in the convention was in favor of the women's liberation groups, but on the other hand it created a new revolution. In the past, people have sex for reproductive purposes, but now people have sex for recreational purposes.

With the increased awareness of human rights, gender equality and the decision made in Cairo convention, GLTBQI movement (Gay, Lesbian, Transgender, Bisexual, Queer and Intersex) started to emerge in community. This phenomenon along with technological revolution has facilitated revolutionary ideology. Technological revolution, particularly telecommunications facilitate all forms of behavior that are based on a normative perspective are considered as abnormal. Nowadays more people take refuge under human rights and gender. The 
principle is that "as long as I don't harm other people". Currently, police are made defenceless. When the police take an action to arrest an anarchist mob, they are charged with human rights violations and police brutality, but when the anarchist mob throw rocks and molotov cocktails to the police, the mob walk free as if they do not violate human rights. It was ironic that three members of municipal police (Satpol PP) died because of a mass movement (trampled to death when they were helpless) but it was the municipal police who were asked to be evaluated.

\section{Closing Statement}

Finally, I would like to ask you to reflect on the industrial revolution that has spurred the growth of industry in all parts of the world. Industrialization, has inevitably led to the exploitation of natural resources, environmental degradation and ultimately, climate change. The ease and comfort as a result of the revolution has led to a new consumptive lifestyle causing exploitation of natural resources. Changes in information technology are like a blade of the sword that is very dangerous when it is used by people who do not understand or misuse it. The most significant impact of social change or globalization on behavior is associated with sexual behavior and personality of people who are creative but have no empathy. Therefore, education and family function unit will become an important agenda in the future.

The role of the family should be given more serious attention because capitalism may start to enter education. Nowadays not only pre-schools and full-day schools exist but also baby schools. This may be because of the lack of parental care that leads to diminished parental attachment. We need to reestablish the three centers of education (families, communities and schools) in order to develop a sense of love and caring towards the environment. Thus, environmental damage can be prevented or at least minimized. Issues concerning climate change to prevent environmental problems in Kalimantan may be significant in the coming era.

\section{References}

Cascio, W. F. (1998). Applied psychology in human resource management (5th ed.). Upper Saddle River, NJ: Prentice Hall, Inc.

Shari, I. (1999). Bumi semua manusia : Menangani ketidaksetaraan ekonomi dalam arus globalisasi. Syarahan Perdana Jawatan Professor. 15 September 1999. Bangi, Unisersiti Kebangsaan Malaysia.

Soeparno, K. (1998). Understanding Prostitution from Rural Communities of Indonesia (Unpublished dissertation). Melbourne: La Trobe University.

Soeparno, K. (2003). Anak jalanan dalam perspektif psikologi: Sebuah evaluasi kebijakan. In Ikatan Psikologi Perkembangan Indonesia (Ed.), Panduan Temu Ilmiah III dan Kumpulan Makalah. Yogyakarta: IPPI.

Vago. S. (2004). Social change. Upper Saddle River, NJ.: Pearson Prentice Hal, Inc.

Zakiya. Z. (2013). Enam dampak perubahan iklim (published in National Geographic Indonesia). Retrieved from Kompas.com (Sunday; March 2, 2014). 